\title{
URGENSI KETERLIBATAN WALI ASUH DALAM DINAMIKA PENDIDIKAN DI PESANTREN
}

\author{
Alfi Najmatil Ilmy, Abd. Hamid Wahid, Chusnul Muali \\ (Universitas Nurul Jadid Paiton Probolinggo)
}

\begin{abstract}
Abstrak:
Wali asuh dalam pesantren berperan dalam menanggulangi penurunan efektifitas kegiatan santri yang diakibatkan semakin banyaknya jumlah peminat pesantren modern dan semi modern dewasa ini. Intisari dari adanya wali asuh adalah sebuah ide pembaruan di pesantren sebagai upaya meningkatkan efektifitas kegiatan dan memudahkan pemantauan aspek psikis santri secara perorangan. Penelitian ini menggunakan pendekatan studi kasus di pesantren Nurul Jadid yang berlokasi di Kabupaten Probolinggo. Hasil penelitian menunjukkan beberapa strategi yang harus dilakukan wali asuh dalam perannya sebagai pengganti orang tua santri. Pertama, wali asuh melakukan pendekatan awal dengan menjadi pendengar yang baik santri asuh untuk menghimpun informasi tentang dunia kehidupannya. Kedua, pemeran wali asuh harus berbeda dengan pemeran pengurus harian untuk memberikan ruang pendekatan pribadi, bukan kolektif. Ketiga, wali asuh berperan pula sebagai motivator, konselor dan pengganti orang tua bagi santri asuh.
\end{abstract}

Kata Kunci: Wali asuh; Konselor; Pesantren; Nurul Jadid. 


\begin{abstract}
:
Guardianship in pesantren functions to solve the decrease of effectiveness of santri's activities along with the increase of new santri in number within modern and semi-modern pesantren. The core values of guardianship here is an innovation in pesantren to increase impact of activities and to make ease individual monitoring towards santri's psychological and life aspects. This research implements case study approach to Pesantren Nurul Jadid located in Probolinggo Regency. Results show several strategies in the guardianship implementation in order to substitute parental roles. First, guardians act as listeners to santri in order to collect their life-aspect information. Second, guardians are individually different from those acting as pesantren daily committee member in order to provide more private approach to santri rather than a collective one. Third, guardians act as motivators, counselors, and parents for santri during their study in pesantren.
\end{abstract}

\title{
Keywords: Guardian; Counselor; Pesantren; Nurul Jadid.
}

\section{A. Pendahuluan}

Pendidikan dengan segala permasalahannya, tetap menjadi elemen utama dalam upaya meningkatkan kualitas sumber daya manusia. Pendidikan memberikan kemampuan kepada suatu komunitas untuk melihat kemungkinankemungkinan yang terbuka di masa depan. ${ }^{1}$ Pendidikan yang bertujuan untuk berkembangnya potensi peserta didik agar menjadi manusia yang beriman dan bertakwa kepada Tuhan yang maha esa, berakhlak mulia, sehat, berilmu, cakap, kreatif, mandiri, dan menjadi warga negara yang demokratis serta bertanggungjawab harus benar-benar dikelola dengan baik. ${ }^{2}$ Terlebih saat ini, terdapat begitu banyak pilihan konsep pendidikan yang ditawarkan bagi masyarakat, salah satu diantaranya adalah pesantren.

Secara umum, pendidikan pesantren saat ini mengalami perkembangan yang cukup signifikan. Pesantren sebagai lembaga pendidikan keislaman tertua di Indonesia, belum melengkapi dirinya dengan elemen penting dalam pendidikan dan pembelajaran yang konkrit layaknya pendidikan formal pada umumnya. Semisal, ketersediaan kurikulum pendidikan yang sistematis, hingga pada sarana dan prasarana yang memadai. Hal ini menjadi wajar, tatkala mendeskripsikan pesantren sebagai lembaga pendidikan non formal yang tidak terikat dengan regulasi apapun. Namun, tidak sedikit pesantren di Indonesia perlahan mulai keluar dan membuka diri dari tradisi dan rutinitas pendidikan

${ }^{1}$ Hasan Baharun dan Robiatul Awwaliyah, "Pendidikan Multikultural dalam Menanggulangi Narasi Islamisme di Indonesia," Jurnal Pendidikan Agama Islam (Journal of Islamic Education Studies) 5, no. 2 (2017): 224-243.

2 Chusnul Muali, "Rasionalitas Konsepsi Budaya Nusantara dalam Menggagas Pendidikan Karakter Bangsa Multikultural," Jurnal Islam Nusantara 1, no. 1 (2017): 105-117. 
yang selama ini dianggap konvensional dan jauh dari modernisasi. Saat ini, terdapat beberapa pesantren di Indonesia yang memiliki kualitas pendidikan yang tidak hanya setara, bahkan melebihi perolehan standarisasi pendidikan formal. Hal ini menjadi daya tarik tersendiri bagi masyarakat. Bagaimana tidak, pesantren dengan segala keterbatasan yang dimilikinya.

Hal ini menjadi berbanding terbalik dari pesantren yang semula sangat kurang diminati oleh masyarakat, menjadi pendidikan yang paling di minati para orang tua untuk keberlangsungan pendidikan anak-anaknya. Akibatnya kini banyak pesantren yang lebih memilih untuk membawahi beberapa sekolah formal agar eksistensi pesantren tetap terjaga dan diminati.

Dengan semakin diminatinya pendidikan pesantren, bukan berarti sistem didalamnya berhenti begitu saja dan tidak melakukan perbaikan lagi. Justru dari sanalah akan semakin tampak hal yang sebelumnya tidak perlu menjadi sangat dibutukan adanya.

Sebagai salah satu pesantren di kabupaten Probolinggo, pondok pesantren Nurul Jadid telah ditata dalam sebuah formulasi atas sebuah khazanah intelektual yang mumpuni. Pesantren yang kini sudah memiliki lebih dari 10 ribu santri tersebut sangat tidak mungkin dengan jumlah pengurus yang hanya berkisar ratusan akan sanggup mengontrol serta mengkondisikan ribuan santri yang ada. Imbasnya banyak kegiatan yang tidak berjalan secara maksimal, banyak aktifitas santri yang tidak terkontrol dan parahnya banyak pelanggaran yang tidak diinginkan terjadi akibat kurang terkontrolnya aktifitas santri diluar kegiatan yang ada.

Maka, disinilah peran wali asuh sangat dibutuhkan. Wali asuh adalah beberapa pengurus dibawah naungan kepala bagian Bimbingan dan Konseling yang bertugas dalam pembinaan spiritual dan emosional beberapa santri. Pembinaan spiritual meliputi: pembinaan Al-Qur'an, Furudul Ainiyah dan akhlak santri. Dan untuk pembinaan emosional santri adalah mengayomi dan membina dalam pembentukan karakter santri serta menjadi konselor bagi santri yang kurang disiplin dalam mentaati peraturan pesantren. Selain itu wali asuh mempunyai tugas yang sama persis layaknya orang tua kepada anaknya, maka eksistensinya berperan sentral bagi efektifitas kegiatan santri, dari aktifitas spiritual sampai emosional santri, dari yang masih akan dilaksanakan sampai yang sudah akan di evaluasi. Dengan adanya wali asuh ini, bukan berarti untuk membuat santri manja kepada wali asuh sehingga menghilangkan budaya mandiri di Pesantren. Namun, wali asuh ini bertugas untuk mengontrol, memotivasi, membimbing serta menjadi konselor guna membantu dalam efektifitas pelaksanaan kegiatan pesantren maupun pribadi santri. 
Di Pesantren Nurul Jadid wilayah Az-Zainiyah ${ }^{3}$ setiap wali asuh mempunyai tugas membina 8-10 anak asuh. Mereka disebar di beberapa daerah untuk menjadi pengurus daerah sekaligus wali asuh. Wali asuh layaknya pengganti orang tua selama di pesantren, karena wali asuh bertugas 24 jam dalam pengontrolan Anak Asuh. Dari mulai kegiatan sekolah, diniyah, pribadi sampai kegiatan pesantren anak asuh wajib diketahui oleh wali asuh.

\section{B. Menilik Pendidikan Pesantren; Berdasarkan Jenis, Kelemahan dan Keunggulan}

Dewasa ini dalam arus perkembangan, pola pendidikan di pesantren telah berkembang dari tradisional menjadi modern. ${ }^{4}$ Hanya saja, masih ada beberapa pondok pesantren yang lebih memilih bertahan dalam pola pendidikan tradisional. Selain itu dunia modern tampaknya turut mengubah relasi antara kiai pesantren modern dengan santri, dari relasi paternalistik menjadi relasi yang semakin fungsional. Seorang kiai kini tak lagi mengurusi semua hal tentang pesantren. Pengelolaan pesantren modern diserahkan sepenuhnya kepada para pengurus. Pengurus disini kebanyakan dari santri senior yang telah lama mengabdi dan sudah pastimengetahui banyak hal mengenai kepesantrenan. Selain santri senior keluarga pengasuh seperti putra atau cucu keluarga pesantren juga ikut serta dalam kepengurusan pesantren. Selain itu, kini banyak pesantren modern yang sekaligus dijadikan sebuah yayasan, guna berjaga-jaga akan eksistensi pesantren meskipun setelah meninggalnya kiai, karena bisa saja para keluarga pengasuh tidak mau atau tidak mampu melanjutkan fungsi pengasuh sebelumnya. ${ }^{5}$

Dalam dunia pesantren, kekayaan tradisi yang berkelindan dapat dijadikan modal menuju puncak sebuah tradisi dan kejayaan baru. Dalam konteks ini, sistem pendidikan sangat berpengaruh dalam membentuk tradisi. Di tengah tuntutan pesantren untuk bisa melewati fase transisi menuju penguatan tradisi pada zaman modernisasi ini, pesantren juga dituntut untuk memperkuat dasar-dasar metodologi pendidikannya. Hal penting yang perlu dirumuskan kembali ketika membincang dunia pesantren adalah sistem, tradisi, dan proses pendidikan pesantren yang dapat menjamin keberlangsungan ruh pendidikan itu

3 Akmal Mundiri dan Irma Zahra, "Implementasi Metode STIFIn Dalam Meningkatkan Kemampuan Menghafal Al-Qur'an Di Rumah Qur'an STIFIn Paiton Probolinggo," Jurnal Pendidikan Agama Islam (Journal of Islamic Education Studies) 5, no. 2 (2017): 201, http://jurnalpai.uinsby.ac.id/index.php/jurnalpai/article/view/108.

4 Hasan Baharun, "Manajemen Strategi Peningkatan Mutu Pendidikan Pondok Pesantren (Studi Di Pondok Pesantren Nurul Jadid Paiton Probolinggo)” (Tesis Program Pascasarjana, Universitas Islam Negeri, 2006).

${ }^{5}$ Ahmad Muhakamurrohman: "Pesantren: Santri, Kiai, dan Tradisi," Jurnal Kebudayaan Islam Vol. 12, No. 2, (Juli - Desember 2014). 
sendiri. Jalan keluar dari konteks diatas adalah tetap mempertahankan tradisi lama yang dirasa perlu dan tidak menolak wawasan baru yang sebelumnya sudah menggunakan terlebih dahulu, sejauh mana wawasan baru itu diperlukan dan batasan-batasnnya. Tradisi lama yang menjadi corak khas pesantren dan dirasa perlu dipertahankan sampai saat ini ialah, sorogan kitab klasik atau biasa disebut kitab kuning. Kitab klasik harus tetap menjadi corak khas sebuah pesantren, melihat terjemahan kitab klasik yang kini sudah bisa diakses di berbagai media online ataupun offline tidak terjamin kebenarannya, sudah banyak oknum-oknum tertentu menggeser makna dan maksud untuk kepentingan tertentu. Maka output pesantren yang pasti akan terjun di masyarakat, harus tetap membiasakan diri memahami isi kitab klasik agar tidak salah dalam memberikan jawaban atau pengertian akan suatu hal kepada masyarakat luas. ${ }^{6}$

Dari fisik, infrastruktur, dan sistem pendidikan, pesantren modern dapat dengan mudah dibedakan dari pesantren salafi atau pesantren tradisional. Bangunan-bangunan pesantren modern lebih bersih dan terawat, adanya dapurdapur siap saji, adanya pakaian seragam, auditorium megah, lapangan olahraga, ruang pengembangan bakat dan keterampilan, hingga laboratorium bahasa. Jikalau dalam pengajian bandongan para santri dalam mengaji tidak ada kewajiban hadir, dalam pesantren modern sudah mulai menata struktur pembelajarannya melalu sistem absensi. Sistem dan pembekalan yang dirancang juga sudah sedemikian rupa, guna mempersiapkan santri menghadapi arus modernitas. Segala fasilitas lantas tidak dapat kita tolak begitu saja, karena memang hal tersebut diperlukan untuk menjaga eksistensi pesantren serta mempertahankan output yang mampu bersaing di era milenial ini. Jika pesantren mampu mempertahankan ruh pendidikan serta tradisinya yang positif dan lantas mengembangkan sisi yang belum optimal, niscaya pesantren akan mampu untuk terus memberikan sumbangsih positif bagi kehidupan bangsa Indonesia. ${ }^{7}$

Wacana terbaru akan pendidikan pesantren adalah banyaknya perubahan yang terjadi dengan sistem didalamnya. Faktor yang mendorong terjadinya perubahan dalam pesantren diantaranya adalah tuntutan kebutuhan masyarakat terhadap model pendidikan agama yang beragam. Maka dalam hal ini, pendidikan pesantren bukan serta merta selalu merubah untuk pencitraan semata. Tetapi perlunya menjaga eksistensi dengan selalu melakukan evaluasi terhadap perbaikan sistem untuk perkembangan pesantren kedepan agar tidak kalah saing dengan lembaga pendidikan lain.

Terdapat dua jenis pesantren. Pertama yaitu Salafiyah dikenal juga dengan sebutan pesantren salafi, dimana pesantren salafi masih tetap bertahan

\footnotetext{
${ }^{6}$ Muhakamurrohman: "Pesantren: Santri, Kiai, dan Tradisi,"

7 Clifford Geertz, Abangan, Santri, dan Priyayi dalam Masyarakat Jawa (Jakarta: Pustaka, 1981), 242.
} 
dengan sistem pendidikan tradisionalnya dengan membekali dan menanamkan tradisi ilmiah dan amaliyah Salafus Shalih. ${ }^{8}$ Mereka masih menerapkan sorogan, bandongan, dan hafalan sebagai metode-metode utama dalam pembelajaran. Kajian yang dilakukan hanya terbatas pada kitab kuning. Ilmu pengetahuan umum sama sekali tidak dimasukkan dalam kajian pesantren. Seperti pesantren Tegalrejo Magelang, Pesantren Lirboyo Kediri, dan lain-lain. ${ }^{9}$

Kedua, Pesantren yang berjenis khalafiyah adalah pesantren yang lebih dikenal dengan sebutan pesantren modern. Yaitu pesantren yang memiliki sistem pembelajaran yang sistematik dan memberikan porsi yang cukup besar untuk mata pelajaran umum. Pembelajaran dilaksanakan di kelas. Referensi utama dalam materi keislaman bukan kitab kuning, melainkan kitab-kitab baru yang ditulis para sarjana muslim abad ke 20-an. Ciri khas pondok modern adalah tekanannya yang sangat kuat kepada pembelajaran bahasa, baik Arab maupun Inggris. Aktivitas pembelajaran bahasa tidak hanya dilakukan dalam kelas, tetapi juga praktik percakapan sehari-hari di lingkungan pesantren. ${ }^{10}$

Dari dua pengertian diatas pesantren Nurul Jadid tidak termasuk diantara salah satunya. Karena meskipun sistem pembelajaran yang digunakan telah cukup sistematik ditambah dengan pendalaman beberapa bahasa asing yaitu Arab, Inggris dan Mandarin juga mata pelajaran umum cukup mendominasi di pesantren tersebut. Namun sampai saat ini penerapan pendidikan tradisional tidak pernah terhapus ataupun ditinggalkan, seperti kegiatan sorogan kepada kiai, bandongan dan hafalan pun masih tetap terjaga dan dilestarikan, sehingga kepadatan kegiatan santri sudah tidak dapat dihindari lagi. Maka dapat disimpulkan bahwa pesantren Nurul jadid dapat dikategorikan dalam jenis pesantren yang menengahi kedua jenis diatas yaitu dapat disebut pesantren semi modern. Dengan ini urgensi wali asuh semakin tampak fungsi dan manfaatnya ialah untuk memudahkan dalam pengontrolan individu santri secara intens, guna kepadatan kegiatan pesantren tidak lagi menjadi kendala utama dalam keberlangsungan kegiatan pesantren agar berjalan efektif dan efisien.

Karakter kuat pesantren salaf adalah konsep barokah dan takzir, akan tetapi bukan berarti pesantren Nurul Jadid yang dikategorikan jenis pesantren semi modern tidak menerapkannya. Ngalap barokah kiai dan guru masih menjadi kepercayaan yang diaktualisasikan dalam keseharian santri, seperti sungkem ta'dzim apabila berpapasan dengan keluarga pengasuh yang sesama muhrim. Karena di setiap pengajian baik kiai maupun ustadz, santri selalu di

8 Hasan Baharun, Pengembangan Kurikulum: Teori Dan Praktik (Konsep, Prinsip, Model, Pendekatan Dan Langkah-Langkah Pengembangan Kurikulum PAI) (Yogyakarta: Cantrik Pustaka, 2017), 337.

9 Arief Subhan, Lembaga Pendidikan Islam Indonesia Abad ke-20 Pergumulan Antara Modernisasi dan Identitas, (Jakarta: Kencana, 2012), 128.

10 M. Bambang Pranowo, Islam Faktual, Antara Tradisi dan Relasi Kuasa, (Jakarta: Adicita Karya Nusa, 1998), 53-74. 
doktrin tentang barokah dan lain sebagainya. Doktrin yang ada dipesantren selama ini adalah jika santri taat pada aturan dan mengikuti kegiatan pesantren, aka nada barokah yang mengalir meski dia tidak pintar. Hal inilah yang kemudian menjadi sesuatu yang sangat diharap dan diinginkan oleh santri. Karenanya, mereka berlomba-lomba untuk mendapatkan keberkahan itu dengan (1) Menaati peraturan (2) Mengikuti kegiatan Pesantren (3) Mengabdi kepada Pesantren seperti halnya dengan menjadi wali asuh (4) Ngalap berkah dari pengasuh. Meskipun tidak seperti pesantren salaf yang sepenuhnya kiai dan keluarga pengasuh terjun langsung dalam keseharian kegiatan santri dan selalu bisa setiap saat ngalap barokah guru seperti halnya membenarkan letak tetean (sandal) kiai, karena memang pesantren salaf jumlah santri lebih sedikit sehingga lebih mudah bagi kiai dalam pengondisiannya.

Sama halnya dengan konsep takzir (sanksi), Pesantren Nurul Jadid masih melestarikannnya sampai saat ini walaupun dengan maksud yang sama namun dengan cara dan istilah yang berbeda. Di pesantren Nurul Jadid khususnya wilayah Az-Zainiyah istilah takzir diganti dengan istilah "konsekuensi logis" karena memang sanksi yang diberikan bukan berupa hukuman berat seperti dipecut, disiram air got dan lain sebagainya. Konsekuensi logis disini lebih berupa hukuman yang mendidik dan diterima secara logika santri, seperti konsekuensi dari melakukan kesalahan ringan adalah membaca istighfar 100 kali sambil berdiri, mengahafalkan surat-surat pendek atau mengahafal beberapa hadis. Hal ini dimaksudkan agar selain bertujuan untuk menimbulkan efek jera secara tidak langsung sekaligus menambah porsi pembeleajran yang diterima santri. Lantas karena memang pada dasarnya pesantren Nurul jadid bukan murni pesantren salaf, maka kedua hal diatas tidak lantas dapat mengondisikan santri dengan baik, melihat realita saat ini pengaruh budaya luar sudah sangat tampak dan menjadi ancaman besar bagi ketentraman proses pendidikan pesantren yang semula aman-aman saja. Maka pendekatan intens dari seorang wali asuh masih sangatlah dibutuhkan untuk meredam gejolak budaya luar yang bisa kapan saja menyerang pergaulan maupun psikologi santri.

\section{Konsepsi Wali Asuh}

\section{Pola Asuh Orang Tua dalam Wali Asuh}

Pola asuh atau yang biasa disebut dengan pola interaksi antara orang tua dan anak yaitu bagaimana cara, sikap, atau perilaku orang tua saat berinteraksi dengan anak, termasuk cara bagaimana menerapkan aturan, mengajarkan nilai atau norma-norma yang benar, memberikan perhatian dan kasih sayang yang cukup serta menunjukkan sikap dan perilaku yang baik sehingga dianggap patut untuk dijadikan panutan bagi anaknya. Pola Asuh orang tua adalah langkah tepat sekaligus cara paling efisien yang dapat dijadikan langkah awal bagi orang tua, dalam mendidik anak sebagai wujud nyata dari rasa tanggung jawab kepada 
anak, dikarenakan Pola Asuh merupakan konsep dasar tentang cara interaksi orang tua terhadap anak. ${ }^{11}$

Aspek pola asuh orang tua yang sangat penting pada anak adalah penerimaan dan kontrol. Penerimaan adalah dukungan dan kasih sayang yang terlihat dari senyuman, pujian, dan dorongan. Kontrol mengacu pada pengawasan terhadap aktivitas anak. Sudah seyogyanya orang tua yang selalu memberikan dukungan, baik moril ataupun materil kepada anak serta mengawasi aktifitas keseharian anak, karena dari sanalah motivasi terbesar anak akan tercipta dengan sendirinya. ${ }^{12}$ Pola asuh ini tampak dari pelaksanaan peranan keluarga dalam menunjang keberhasilan anak. Dalam hal ini, terdapat empat prinsip peranan keluarga, yaitu modeling, mentoring, organizing, dan teaching. ${ }^{13}$

Kendati begitu, individu (anak) yang memiliki keterikatan lebih dekat, lebih terikat dan lebih diterima oleh orangtuanya, maka tingkat harapan yang dimiliki anak tersebut akan jauh lebih tinggi dibanding yang tidak dekat dengan orang tuanya. Motivasi terbesar seorang anak, bisa dilihat dari sejauh apa dia dekat dengan orang tuanya, juga sepeduli apa orang tua terhadap kehidupan sang anak. Hal ini menjadi faktor penunjang terbesar bagi anak dalam menjalani kehidupan. ${ }^{14}$ Orangtua yang menerima dan terlibat dengan anak akan menumbuhkan harapan pada remaja. Harapan yang tinggi pada remaja akan menghasilkan optimisme, kontrol diri, kemauan memecahkan masalah, daya saing dan harga diri pada remaja. Hal ini membuktikan bahwa keterlibatan orang tua, motivasi, kepedulian dan kedekatannya berperan aktif dalam tumbuh kembang anak menjadi pribadi yang lebih optimis dan percaya diri. Selain itu juga menimbulkan hubungan yang positif dan signifikan terhadap efikasi diri dan harga diri. ${ }^{15}$

Perilaku agresif adalah salah satu bentuk tindakan diskriminatif, yang bertentangan dengan norma-norma yang berlaku pada masyarakat bisa disebut

11 Putri Risthantri, Ajat Sudrajat, "Hubungan Antara Pola Asuh Orang Tua Dan Ketaatan Beribadah Dengan Perilaku Sopan Santun Peserta Didik", Jurnal Pendidikan IPS, Vol. 2, No. 2, (September 2015).

12 DR. Shaffer \& Kipp K, Developmental Psychology: Childhood and Adolescence, 9th Edition. (Canada: Wadswort Cengage Learning, 2014), 541.

13 Yusuf, S. Psikologi Perkembangan Anak \& Remaja. (Bandung: PT. Remaja Rosdakarya, 2008), 47.

${ }^{14}$ Shorey, H.S., Snyder, C. R., Yang, X. \& Lewin, M.R.. "The Role of Hope as a Mediator in Recollected Parenting, Adult Attachment and Mental Health," Journal of Social and Clinical Psychology (2003): 685-715.

15 Aydin B., Sari Serkan V., Sahin M. "Parental Acceptance/Involvement, Self-Esteem and Academic Achievement: The Role of Hope as a Mediator," Cumhuriyet International Journal of Education-CIJE, (2014): 37-48. 
sebagai perilaku negatif atau anti sosial, sehingga memerlukan penanganan khusus agar perilaku negatif atau anti sosial tersebut menjadi perilaku yang positif atau yang bersosial. Beberapa perilaku agresif siswa misalnya marahmarah, menghina, mengkutuk, mengkritik, bertengkar, menyindir, menyalahkan dan menertawakan. Hal ini sering terjadi yang berdampak besar pada interaksi individu, Dimana perilaku agresif yang dilakukan oleh remaja cukup banyak terjadi di Indonesia. 16

Seperti yang terjadi pada bulan Maret 2014, seorang remaja bernama Mia, berusia 16 tahun meninggal karena disiksa oleh mantan pacar dan temantemannya. ${ }^{17}$ Selain itu terdapat satu penelitian yang menyatakan bahwa sebagian besar siswa SMAN 70 Jakarta Selatan memiliki perilaku agresif tinggi. Hal ini patut menjadi wacana bagi para orang tua untuk waspada, serta menjadi PR untuk selalu mengupayakan kontrol terhadap aktifitas keseharian anak, guna meninjau lebih intensif perkembangan psikologis anak diluar ataupun didalam rumah. ${ }^{18}$ Karena perilaku agresif bisa disebabkan oleh berbagai faktor, seperti kurang diperhatikan, tertekan, pergaulan buruk dan efek dari tayangan kekerasan di media massa. Maka kontrol dan perhatian orang tua tidak berhenti pada masa kanak-kanak saja, justru pada masa remaja itulah masa pubertas dan kelabilan seorang anak perlu dicermati. Banyak hal yang bisa saja terjadi akibat pengaruh lingkungan sekolah, teman maupun media sosial yang kini sudah bisa diakses kapanpun dan dimanapun. ${ }^{19}$

Untuk menghindari perilaku agresif, maka penanaman sopan santun diperlukan di lingkungan keluarga. Anak akan meniru perilaku orang tua dalam kehidupan sehari-hari. Anak yang mempunyai perilaku sopan pada umumnya berasal dari keluarga yang juga sopan, demikian pula sebaliknya anak yang mempunyai perilaku kasar tentunya perilaku keluarga juga kasar. Upaya menanamkan sopan santun di dalam keluarga yaitu dengan cara orang tua memberikan contoh-contoh penerapan perilaku sopan santun di depan anak. Demikian pula di sekolah, guru harus memberikan contoh perilaku sopan santun. Masalahnya, guru pada umumnya lebih fokus pada pencapaian prestasi akademik semata. Akhlak adalah pondasi utama dalam kehidupan manusia dan

16 Zain Irwanto, "Perilaku Agresif dan Penangananya Melalui Konseling Islami", Jurnal Psikologi Pendidikan \& Konseling, Vol. 3 No. 1, (Juni 2017).

17 Dini, F. O., dan Indrijati, H, "Hubungan antara Kesepian dengan Perilaku Agresif pada Anak Didik di Lembaga Pemasyarakatan Anak Blitar". Jurnal Psikologi Kepribadian Dan Sosial, (2014).

18 Waluya, O. D., dan Rakhmadianti, A. K., "Perilaku Agresif ditinjau dari Jenis Tontonan Film pada Siswa SMAN 70 Jakarta Selatan". Jurnal Psikologi. Vol. 6. No. 2 (2008).

${ }^{19}$ Restu, Y. dan Yusri. Studi tentang Perilaku Agresif Siswa di Sekolah. Jurnal Ilmiah Konseling, 2(1). (2013), 243-249. 
sopan santun adalah bagian aplikasi dari akhlak. Sehingga perlu penanaman sejak dini praktik sopan santun yang baik dalam lingkungan keluarga. ${ }^{20}$

Sopan santun merupakan perwujudan budi pekerti luhur yang diperoleh melalui pengalaman, pendidikan, dan teladan dari orang tua, guru, para pemuka agama, serta tokoh-tokoh masyarakat. Sopan santun merupakan tata krama dalam kehidupan sehari-hari sebagai cerminan kepribadian dan budi pekerti luhur yang di dalam Islam lebih dikenal dengan konsep akhlak. Orang tua adalah teladan utama dalam pengaplikasian sopan santun, karena orang tua adalah cerminan bagi anak-anaknya. Terutama seorang ibu, sebagai orang yang melahirkan anak, maka tidak menutup kemungkinan seorang anak akan menganggap bahwa ibu adalah orang yang sangat berjasa dalam hidupnya sehingga sosoknya patut ditiru dan dijadikan contoh. ${ }^{21}$ Sopan santun juga merupakan cerminan akhlak yang dapat dicapai melalui proses pembelajaran anak di sekolah. Transfer pengetahuan yang diukur dengan nilai belum mampu membentuk pribadi yang berakhlak mulia. Sopan santun justru bergantung pada bagaimana proses pembinaan akhlak anak. Akhlak selalu melekat dan tampak dalam bentuk perbuatan. Selain di lingkungan keluarga, sopan santun juga perlu ditanamkan dalam lingkungan sekolah, yaitu oleh segenap civitas akademika sekolah, terutama guru. Guru dengan segala pembelajaran yang ditransfer kepada peserta didik, membuat siswa percaya bahwa guru adalah orang yang paling pintar dan perkataanya selalu benar. Maka tidak menutup kemungkinan pula bahwa guru sebagaimana semboyan yang sering dilekatkan pada guru yaitu guru adalah seseorang yang digugu dan ditiru. ${ }^{22}$

Ada perbedaan yang menonjol pada konsep pengasuhan dalam pola asuh orang tua. Perbedaannya terletak pada konsep pengasuhan, ketika anak dilihat sebagai sosok yang sedang berkembang, maka konsep pengasuhan yang diberikan berupa konsep psikologi perkembangan. Sedangkan ketika konsep pengasuhan mempertahankan cara-cara yang tertanam didalam masyarakat, maka konsep yang digunakan adalah tradisional. Penerapan konsep pengasuhan ini, melihat dari faktor individual anak. Konsep pengasuhan tradisional digunakan, apabila anak yang bersangkutan masih saja terbiasa dengan adat dan kebiasaan yang sudah ada di masyarakat. Sebaliknya, apabila anak yang

20 Ujiningsih dan Antoro, S.D. Pembudayaan sikap sopan santun di rumah dan di sekolah sebagai upaya untuk meningkatkan karakter siswa, Makalah disampaikan dalam Temu Ilmiah Nasional Guru II 2010 Universitas Terbuka. (2010), 2.

21 Marzuki. Prinsip Dasar Akhlak Mulia Pengantar Studi Konsep-Konsep Dasar Etika dalam Islam, (Yogyakarta, Debut Wahana Press, 2009), 8.

22 Mu'niah. Materi Pendidikan Agama Islam untuk Perguruan Tinggi, (Yogyakarta: Ar-Ruzz Media, 2011), 104. 
bersangkutan terlihat lebih bisa menerapkan hal yang lebih dari itu, maka konsep yang digunakan adalah Psikologi Perkembangan. ${ }^{23}$

Gaya pengasuhan authoritative dan authoritarian memiliki korelasi yang tinggi pada harapan. Harapan pada anak dibentuk oleh dukungan sosial terutama oleh orangtua. Orangtua yang mendukung dan terlibat langsung dengan anak, akan memiliki harapan yang lebih tinggi dibandingkan dengan anak yang tidak memiliki kedekatan emosional dengan orangtua mereka. Orang tua adalah manusia pertama yang terlihat oleh anak ketika terlahir ke dunia, sedangkan orang tua adalah dua subjek yang paling mengenal dengan baik karakteristik seorang anak, karena memang orang tualah yang mengikuti dan mengetahui dengan jelas perkembangan sang anak dari kecil sampai dewasa. ${ }^{24}$

Sementara itu, orang tua tidak boleh menghukum anak, yang benar adalah orang tua harus mengembangkan aturan-aturan bagi anak dalam mencurahkan kasih sayang kepada anak. Sebagai langkah selanjutnya orang tua perlu menyesuaikan perilaku mereka berdasarkan tingkat perkembangan sang anak, karena setiap anak pada dasarnya memiliki kebutuhan dan kemampuan yang berbeda-beda. Apabila seorang anak membuat kesalahan sekecil apapun itu, orang tua tidak patut untuk memberikan hukuman kepada anak. Seharusnya langkah tepat yang harus diambil oleh orang tua, yaitu dengan penyempurnaan aturan-aturan yang selama ini telah diterapkan oleh sang anak, penyesuaian perangai orang tua dengan sang anak, sehingga anak mempunyai figur yang patut untuk dicontoh. Hal ini karena hakikatnya setiap manusia, anak-anak ataupun orang dewasa tidak memiliki kemampuan dan kebutuhan yang sama. ${ }^{25}$

Dengan ini terdapat beberapa tata cara kehidupan keluarga yang akan membentuk sikap serta perkembangan kepribadian anak. Ada tiga jenis tata cara kehidupan keluarga, yaitu: Pertama, Demokratis, anak dibesarkan dalam susunan keluarga yang demokratis, membuat anak mudah bergaul, aktif, dan ramah sehingga anak belajar menerima pandangan orang lain. Kedua, Permisif, anak yang dibesarkan dalam keluarga permisif akan membuat anak tidak aktif dalam kehidupan sosial dan dapat dikatakan anak menarik diri dari kehidupan sosial dan mempunyai kecenderungan untuk mudah membenci seseorang. Ketiga, Otoriter, lingkungan keluarga yang mengaplikasikan otoriter dalam membesarkan anak, biasanya anak akan bersifat tenang, tidak melawan, tidak agresif dan mempunyai tingkah laku yang baik. Anak akan berusaha menyesuaikan pendiriannya dengan kehendak orang lain atau orang yang paling

\footnotetext{
${ }^{23}$ Handayani, W. Psikologi Keluarga. (Jakarta: Pustaka Utama, 2006), 57.

${ }^{24}$ Heaven, P., dan Ciarrochi, J., "Parental Style, Gender and the Development of Hope and SelfEsteem," European Journal of Personality (2008): 22.

25 Papalia, D. E., Wendkos, S., dan Feldman, R. D. Human Development. (Jakarta : Kencana, 2008), 129.
} 
berkuasa penuh bagi anak yaitu orang tua. Dari ketiga cara diatas, cara pertama dan ketiga patut diaplikasikan dalam lingkungan keluarga dengan mengombinasikan keduanya, menggabungkan aktifitas keduanya menjadi acuan dalam mengembangkan karakter anak dalam kehidupan sehari-hari. ${ }^{26}$

\section{Wali asuh sebagai Konselor Islam}

Konseling dalam Islam merupakan suatu aktifitas memberikan bimbingan, pelajaran dan pedoman kepada individu yang meminta bimbingan (konseli), dalam hal bagaimana seharusnya seorang konseli dapat mengembangkan potensi akal fikirannya, kejiwaannya, keimanannya dan keyakinannya, ditambah lagi dengan kiat-kiat tertentu dari konselor, untuk mempermudah konseli menanggulangi problematika kehidupannya dengan baik dan benar secara mandiri, yang berparadigma kepada Al-Qur'an dan As-Sunnah Rasulullah SAW. Konseling merupakan proses bimbingan yang dilakukan oleh seorang konselor dan klien (orang yang meminta bimbingan), tujuannya untuk membantu mengarahkan solusi dari problematika yang dihadapi klien. Juga membantu klien mengenal pribadinya lebih dalam dan mengetahui potensipotensi yang selama ini terpendam dan tidak disadari, untuk dieksplor menjadi kelebihan yang baru dalam dan patut untuk disyukuri. ${ }^{27}$

Terdapat beberapa kriteria konselor Islam diantaranya: Pertama, hendaklah orang yang menguasai materi khususnya dalam masalah keilmuan agama Islam, sehingga pengetahuannya mencukupi dalam hal-hal yang berkaitan dengan masalah keagamaan. Kedua, hendaklah orang yang mengamalkan nilainilai agama Islam dengan baik dan konsekuen, tercermin melalui keimanan, ketakwaan, dan pengalaman keagamaan dalam kehidupan sehari-hari. Ketiga, sedapat mungkin mampu mentransfer kaidah-kaidah agama Islam secara agama Islam secara garis besar yang relevan dengan masalah yang dihadapi klien. Keempat, mempunyai penguasaan tentang metode dan strategi yang tepat dalam menyampaikan bimbingan dan konseling kepada klien, maka klien dengan tulus akan mudah menerima nasihat konselor. Kelima, memiliki pribadi yang terpuji sebagai teladan dalam perilaku baik di tempatnya bekerja maupun diluar tempat bekerja. Keenam, hendaknya menguasai bidang psikologi secara integral, sehingga dalam tugasnya melaksanakan bimbingan dan konseling akan dengan mudah menyampaikan nasihat dengan pendekatan psikologis. ${ }^{28}$

26 Notosoedirdjo, M. dan Latipun, Kesehatan Mental, (Malang: UPT Universitas Muhammadiyah, Malang Press. 2011), 207.

27 Hamdani Bakrana Adz-Dzaky, Konseling dan Psikoterapi Islam, (Yogyakarta: Fajar Pustaka. 2002), 189.

${ }^{28}$ Samsul Munir Amin, Bimbingan dan Konseling Islam, (Jakarta: Amzah, 2010), 269. 
Syarat-syarat pribadi yang harus dimiliki oleh konselor salah satu diantaranya yaitu memiliki kematangan pribadi dan sosial, meliputi kepekaan terhadap orang lain, kebijaksanaan, keajengan, rasa humor, bebas dari kecenderungan-kecenderungan suka menyendiri, mempunyai kemampuan dalam mengambil hikmah dari suatu kesalahan yang telah dilakukan, dengan lapang dada berkenan menerima kritik, berpenampilan sopan dan menyenangkan, sehat jasmani maupun rohani, memiliki suara yang sedap didengar, memiliki daya tarik tersendiri dan bebas dari tingkah laku yang tidak menyenangkan. Seorang konselor selayaknya memiliki kepribadian yang matang dan jiwa sosial yang luas, karena hal ini akan mempermudah proses keberlangsungan proses konseling oleh konselor kepada klien. ${ }^{29}$ Guru BK/konselor yang sensitif atau peka terhadap keadaan, akan mampu mengungkap atau menganalisis apa masalah yang sedang dihadapi oleh klien. Seorang konselor adalah seorang yang tanggap terhadap persoalan klien. Ia dapat bersimpati pada apa yang terjadi dalam diri klien serta berempati terhadap apa yang dirasakan oleh klien. Dalam hal ini Guru BK/Konselor harus sigap terhadap masalah yang terjadi pada siswanya, sehingga apapun yang dapat mengganggu kegiatan belajar siswa bisa ditangani dengan segera oleh Guru BK/Konselor yang bersangkutan. ${ }^{30}$

Kemampuan bersimpati dan berempati yang melampaui dimensi duniawi sebagaimana dalam surat At-Taubah ayat 128:

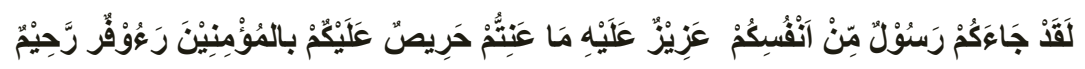

"Sungguh telah datang kepadamu seorang rasul dari kaummu sendiri, berat terasa olehnya penderitaan yang kamu alami, (dia) sangat menginginkan (keimanan dan keselamatan) bagimu, penyantun dan penyayang terhadap orang-orang yang beriman" (Q.S.At-Taubah:128)

Berdasarkan ayat tersebut, dapat dijelaskan bahwa rasulullah adalah manusia sama seperti kita semua, beliau memiliki belas kasih yang sangat besar terhadap ummatnya. Rasulullah juga sangat berharap bahwa seluruh ummatnya beriman, karena itu nantinya akan mengantarkan kepada keselamatan ummatnya. Beruntunglah bagi umat islam yang menjadi umat Nabi Muhammad SAW, karena beliau adalan penyantun dan penyayang terhadap umat yang beriman.

Seorang konselor sudah seharusnya mempunyai akhlak yang mulia karena ia adalah seorang penasehat bagi peserta didiknya. Dalam pandangan

29 Prayitno dan Erman Amti. Dasar-dasar Bimbingan dan Konseling. (Jakarta: Rineka Cipta. 2004), 344.

30 Syamsu Yusuf dan Juntika Nurihsan. Landasan Bimbingan dan Konseling. (Jakarta: PT Remaja Rosdakarya, 2009), 43. 
klien konselor adalah sosok problem solver yang bebas dari kesalahan, dengan attitude yang baik sehingga patut untuk dijadikan cerminan dalam beradab. ${ }^{31}$ Sebagaimana dalam surat Mumtahanah ayat 4:

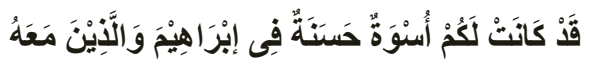

"Sesungguhnya telah ada suri tauladan yang baik bagimu pada Ibrahim dan orang-orang yang bersama dengannya" (Q.S. Mumtahanah:4)32

Berdasarkan ayat diatas bahwa suri tauladan atau sosok yang patut dijadikan contoh, cerminan, panutan dalam beradab dan attitude yang baik yaitu Nabi Ibrahim As dan umat yang mengikuti ajarannya.

Konselor dituntut untuk dapat menemukan cahaya keislaman sebagai qudwah (keteladanan) dan sekaligus menjadikannya sebagai salah satu teknik penyelenggaraan konseling islami, demi terciptanya suatu kondisi keteladanan yang mempengaruhi konseli menuju arah terciptanya insan kamil. Konselor muslim tentu akan memberikan bimbingan yang mungkin sesuai dengan derajat kasus dan derajat halal, mandub , mubah, makruh, maupun haram dalam konteks yang dihadapi klien. Begitu juga wali asuh memberikan bimbingan dalam pembinaan anak asuh berdasarkan fikrah Islamiyah. Maka Konseling Islami secara tatap muka menempatkan konselor pada posisi sentral di hadapan konseli. Oleh karena itu, sifat keteladanan yang dimiliki oleh konselor perlu diekspresikan dalam kehidupan sehari-hari baik selama proses konsultasi maupun diluar kegiatan tersebut, minimal harus diupayakan konseli dapat terkondisikan oleh perilaku konselor baik secara disadari atau tidak. ${ }^{33}$

Dalam hal ini, apabila terdapat beberapa anak mengalami gejala tertentu setelah terjadinya bencana alam, seorang konselor harus berkonsultasi dengan orang tua dan guru si anak, disertai dengan konseling suportif, intervensi krisis, dan sumber daya dan rujukan untuk memenuhi kebutuhan dasar. Namun, apabila beberapa minggu setelah bencana alam berakhir masih dan tetap saja mengalami gejala persisten yang akhirnya mengganggu aktifitas mereka, upaya selanjutnya ialah dengan diadakan proses konseling yang lebih intensif dari sebelumnya. ${ }^{34}$

Secara umum konselor, klien, dan proses konseling dipengaruhi oleh keadaan dan hubungan ras di masyarakat yang lebih luas. Bahwa konselor sudah selayaknya membantu. Sedangkan proses konseling yaitu mencakup nilai dan

${ }^{31}$ Mulyasa. Standar Kompetensi dan Sertifikasi Guru. (Bandung: PT. Remaja Rosdakarya, 2008), 129.

32 Departemen Agama RI, Cordova Al-Qur'an dan Terjemah, (Bandung, PT. Sygma Examedia Arkan leema, 2009), 549.

33 Zain Irwanto, "Perilaku Agresif dan Penangananya,"

34 Jennifer Baggerly and Herbert A. Exum "Counseling Children After Natural Disasters: Guidance for Family Therapists," The American Journal of Family Therapy 36, (2008): 79-93. 
asumsi yang mencerminkan cita-cita demokrasi seperti, semua orang berhak untuk diberi kesempatan, kebebasan dan diperlakukan secara adil oleh dan dengan orang lain. Juga setiap orang berhak bahagia dan mengusahakan kebahagiaannya. Walaupun tidak mayoritas konselor secara realistis mencerminkan dalam praktik konseling yang dilakukannya. 35

Dari berbagai konteks diatas, mengharuskan konselor muslim memiliki bobot yang lebih dari sekedar konselor pada umumnya. Konselor muslim yang komitmen terhadap Islam, tentunya akan memulai membangun dan mengembangkan kepribadiannya sesuai dengan citra Islami. Penggalian terhadap sumber utama al-quran dan sunnah adalah cikal bakal pemahaman yang benar tentang apa yang dapat dilakukan oleh konselor muslim. Begitu juga wali asuh harus juga membangun karakter diri menjadi karakter islam yang lebih baik lagi, ${ }^{36}$ mengingat karakter sangat penting bagi perkembangan anak $\operatorname{didik}^{37}$.

\section{Wali asuh Sebagai Motivator}

Sikap dan tingkah laku atau yang seringkali disebut perangai manusia, didorong oleh motif-motif tertentu. Sedangkan proses belajar akan berhasil apabila didasari dengan motivasi yang ada dan diberikan pada murid. Murid dapat dipaksa untuk mengikuti sesuatu untuk perbuatan, tetapi ia tidak dapat dipaksa untuk menghayati perbuatan itu sebagaimana mestinya. Motivasi menjadi salah satu solusi untuk merubah reaksi seseorang terhadap suatu hal. Sebagaimana murid, seorang guru bisa memotivasi murid untuk mau memperhatikan dan mengikuti proses belajar dikelas dengan tenang. Karena memang motivasi sendiri memiliki makna perubahan energi dalam diri (pribadi) seseorang yang ditandai dengan timbulnya perasaan dan reaksi untuk mencapai tujuan. ${ }^{38}$

Terdapat dua definisi dari motivasi yaitu: Pertama, dorongan yang muncul dari diri seseorang baik secara disadari atau tidak disadari untuk melakukan tindakan dengan tujuan tertentu. Kedua, usaha-usaha yang dapat membuat seseorang atau sekelompok orang untuk melakukan sesuatu agar dapat mencapai tujuan yang diinginkan. Dari dua definisi di atas maka motivasi terbagi menjadi dua jenis. Motivasi yang berasal dari dalam diri seseorang, yang seringkali disebut dengan istilah motivasi intrinsik dan motivasi dari luar berupa

35 Derald Wing Sue, Patricia Arredondo, and Roderick J. Mcdavis "Multicultural Counseling Competencies and Standards," Journal of Counseling \& Development Vol. 70, 479. (March/April 1992).

36 Samsul Munir Amin, Bimbingan dan Konseling Islam, (Jakarta: Amzah, 2010), 263.

37 Hasan Baharun, "Total Moral Quality: A New Approach for Character Education in Pesantren," Ulumuna 21, no. 1 (2017): 57-80.

38 Oemar Hamalik, Proses Belajar Mengajar (PT Bumi Aksara, 2001), 158. 
usaha pembentukan dari orang lain yang sering disebut dengan motivasi ekstrinsik. ${ }^{39}$

Dalam hal ini, motivasi mengandung tiga komponen pokok yaitu menggerakkan, mengarahkan, dan menopang tingkah laku. Seseorang akan termotivasi apabila dia percaya bahwa suatu perilaku tertentu akan menghasilkan hasil tertentu yang mempunyai nilai positif bagi dirinya dan dapat dicapai dengan usaha yang dilakukannya. Ketiga komponen ini adalah unsur yang saling berkesinambungan untuk menciptakan suatu motivasi tertentu oleh seorang motivator kepada seseorang, agar bisa merubah cara berfikir yang monoton menjadi berpandangan luas dan mau mencoba inovasi-inovasi baru untuk perubahan dirinya yang lebih baik. ${ }^{40}$ Motivasi dalam diri dengan proses ketekunan mengulang membaca materi pelajaran, tidak mudah putus asa dalam menyelesaikan tugas, ketertarikan dalam mengikuti pelajaran, merupakan ciriciri siswa yang memiliki motivasi belajar sehingga terwujudnya tujuan dan mendapatkan hasil yang memuaskan dalam proses belajar dan pembelajaran. ${ }^{41}$

Perlu diketahui bahwa motivasi dibedakan menjadi dua macam, yaitu motivasi ekstrinsik dan intrinsik. Pada Intinya motivasi ekstrinsik ialah efek rangsangan yang disebabkan oleh faktor luar situasi belajar, sehingga menimbulkan semangat untuk melakukan atau mengerjakan suatu hal, seperti akan mendapat sepeda apabila lulus ujian. Sementara motivasi intrinsik semangat dan efek rangsangan itu berasal dari dalam diri pribadi itu sendiri. ${ }^{42}$

Motivasi adalah hasil dari interaksi antara harapan akan sukses dengan rasa takut akan mengalami kegagalan. Apabila harapan akan kesuksesan lebih besar dibandingkan ketakutan akan mengalami kegagalan, maka orang tersebut akan termotivasi untuk mencapai tujuannya. Namun, sebaliknya jika ketakutan akan gagal lebih dominan dibanding harapan akan kesuksesannya, maka orang tersebut akan sulit termotivasi untuk mencapai tujuannya. Ditinjau dari uraian diatas, maka motivasi merupakan hasil final dari proses antara harapan akan kesuksesan dan takut akan kegagalan yang akan dihadapi. ${ }^{43}$

Ciri-ciri siswa yang memiliki motivasi tinggi dalam belajar yaitu. Pertama, ketekunan dalam belajar dan tugas. Kedua, keuletan menghadapi kesulitan. Ketiga, menunjukkan ketertarikan dalam belajar. Keempat, kemandirian dalam belajar. Siswa yang memiliki motivasi belajar dilihat dari perhatiannya terhadap proses belajar yang mana menyangkut minat untuk belajar, ketajaman perhatian, konsentrasi dan ketekunan. Setiap siswa yang memiliki motivasi belajar tinggi,

\footnotetext{
${ }^{39}$ Asrori, M. Psikologi Pembelajaran (Bandung: Wacana Prima, 2007), 183.

40 Ngalim, P. Psikologi Pendidikan (Bandung: Sinar Baru Algesindo, 2007), 72.

41 Sardiman. A.M. Interaksi dan Motivasi Belajar Mengajar (Jakarta: Raja Grafindo Persada, 2012), 83.

42 Peters, R. S., The Concept of Motivation (London: Routledge, 1958),

${ }^{43}$ Djaali. Psikologi Pendidikan (Jakarta: Bumi Aksara, 2007), 105.
} 
dia akan menampakkan minat belajar yang besar, perhatian yang penuh terhadap belajar dan tugas tanpa mengenal perasaan bosan, apalagi menyerah. Namun, sebaliknya jika yang dihadapi adalah siswa yang memiliki motivasi belajar rendah, mereka akan lebih menampakkan keengganan, lebih cepat menampakkan kebosanan dan berusaha menghindar dari kegiatan belajar. Perbedaan yang sangat menonjol tampak jelas oleh jenis siswa yang memiliki motivasi belajar tinggi dan rendah, karena memang hal ini dapat dirasakan langsung oleh guru didalam kelas. Dari berbagai sikap dan respon yang diberikan oleh siswa serta antusiasme dalam menanggapi pembelajaran yang diarahkan oleh guru. ${ }^{44}$

Fitur kedua pembelajaran orang dewasa adalah dimensi pengalaman, partisipasi atau terlibat langsung dalam proses belajar. Peserta didik dewasa perlu dilibatkan secara aktif dalam belajar, karena memang keterlibatan langsung dalam pembelajaran dan motivasi tinggi sangat berkaitan erat dengan peningkatan tingkat keberhasilan siswa dan menurunnya nominal siswa yang putus sekolah. 45

Salah satu faktor yang mempengaruhi motivasi belajar adalah kemampuan saat belajar. Kemampuan ini meliputi aspek perhatian, konsentrasi, ingatan, dan daya pikir. Dalam hal ini tidak terkecuali bagi anak yang mempunyai daya pikir rendah dan ingatan yang lemah, meskipun dia mempunyai kemauan untuk berkonsentrasi dan upaya yang dilakukan oleh orang tua atau orang terdekat dengan memberikan motivasi secara intens. Maka sedikit kemungkinan motivasi belajar anak tersebut akan meningkat. Karena memang keempat kemampuan saat belajar tersebut menjadi hal yang akan mempermudah dalam proses motivasi belajar siswa. ${ }^{46} \mathrm{Hal}$ tersebut perlu dibangun secara intensif, mengingat anak adalah aset terpenting dalam suatu keluarga, agama dan bangsa Indonesia. ${ }^{47}$

Menurunnya motivasi belajar pada siswa akan menyebabkan individu kurang bersemangat untuk mengikuti proses pembelajaran. Mood dan konsentrasi adalah suatu komponen yang penting diperlukan untuk aktivitas, minat dan motivasi belajar pada siswa. Apabila terdapat siswa yang malas belajar dan sering membolos, maka hal tersebut akan mempengaruhi motivasi belajar dan prestasi belajar siswa yang bersangkutan. Namun, apabila siswa tersebut tidak mengurangi atau menghentingkan tindakan yang tidak penting, seperti halnya bermain maka hal ini akan mengganggu pikiran dan konsentrasi

\footnotetext{
${ }^{44}$ Sardiman. A.M., Interaksi dan Motivasi, 83.

${ }^{45}$ Kushman J.W. et.al. This isn't the Place for Me: School dropout. In. D. Capuzzi dan D.R. Gross. Eds. Youths at risk: A prevention resource for counsellors, teachers and parents, (Alexandria: American Counselling Association. 2000).

46 Dimyati dan Mudjiono. Belajar dan Pembelajaran. (Jakarta: Rineka Cipta, 2009), 97.

47 Hasan Baharun, "Pendidikan Anak dalam Keluarga; Telaah Epistemologis," Pedagogik 3, no. 2 (2016): 96-107.
} 
siswa tersebut untuk belajar. Banyak hal yang bisa menyebabkan menurunnya motivasi belajar siswa, salah satunya ialah mood dan konsentrasi yang tidak stabil akan menimbulkan perubahan yang signifikan terhadap motivasi belajar siswa. Karena mood dan konsentrasi ini merupakan komponen penting dalam efektifitas proses pembelajaran. ${ }^{48}$

\section{Urgensi Wali Asuh}

Urgensi wali asuh dalam hal mendidik dan membina kegiatan beberapa anak asuh yang sudah menjadi tanggung jawabnya. Bukan itu saja tapi memotivasi anak asuh dalam proses belajar dipesantren. Dengan wali asuh keseharian anak asuh lebih terpantau, karena mayoritas penyebab nakalnya seseorang karena kurang pantauan dan perhatian dari orang-orang disekitarnya.

Wali asuh disini bukan hanya dalam optimalisasi kegiatan pesantren, tapi juga dalam memenuhi kebutuhan perorangan santri akan pengganti sosok orang tua. Yang bisa mengerti kondisi psikologi anak asuh. Seperti apa yang menjadi alasan malasnya mengikuti kegiatan pesantren, berontaknya terhadap salah satu sikap teman, mengapa lebih banyak menyendiri daripada bersosialisasi dengan teman lainnya dan hal pribadi lainnya. Jauh berbeda dengan pengurus karena pengurus lebih memprioritaskan kegiatan pesantren, sedangkan wali asuh lebih kepada mendidik anak asuh secara intens.

Berdasarkan kenyataan yang diterapkan di wilayah Az-Zainiyah Pesantren Nurul Jadid. Seharusnya tugas wali asuh berbeda dengan pengurus. Karena wali asuh membutuhkan waktu ekstra untuk memaksimalkan tugastugas yang dibebankan kepadanya, apabila wali asuh tugas ganda dengan menjadi wali asuh sekaligus pengurus, maka yang ada hanya tumpang tindih kegiatan yang tidak berjalan. Seharusnya jika sudah menjadi wali asuh maka dia tidak lagi menjadi pengurus begitu pula sebaliknya. Karena realita yang ada, tidak terkontrolnya anak asuh secara optimal diakibatkan oleh terlalu sibuknya wali asuh dengan tugasnya sebagai pengurus.

48 Muhibbin, S. Psikologi Pendidikan dengan Pendekatan Baru (Bandung: PT. Remaja Rosdakarya, 2002), 124. 
Posisi wali asuh disini berada di bawah naungan pengurus BK wilayah dan BK daerah.

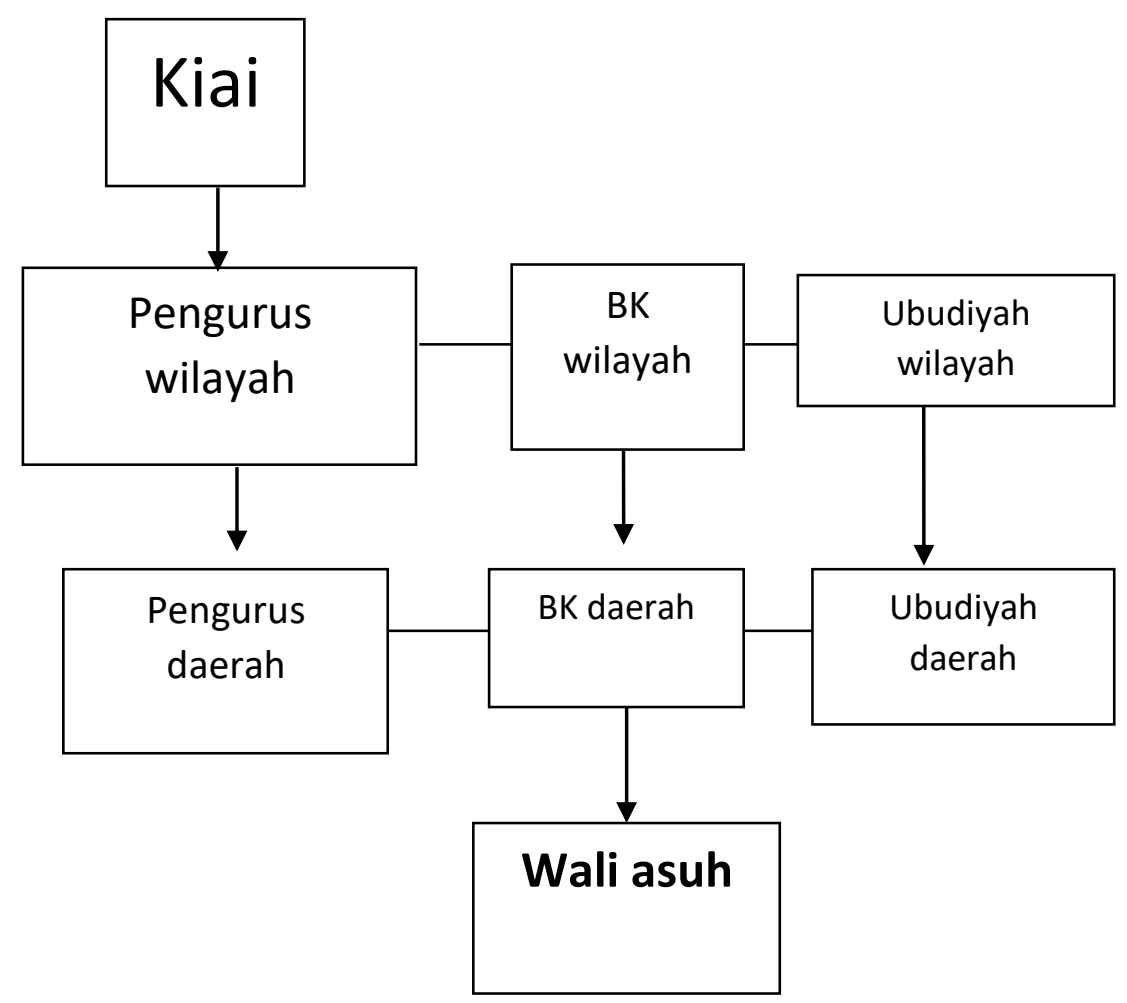

Strategi yang dilakukan wali asuh pertama dengan pendekatan. Pendekatan dimulai dengan menjaga komunikasi yang menyenangkan dengan anak asuh yaitu dengan panggilan sayang kepada anak asuhnya. Karena panggilan sayang akan menimbulkan respon positif pada mereka karena mereka akan menganggap mereka adalah orang penting dan merupakan prioritas. Sebaliknya jika komunikasi awal dimulai dengan panggilan kaku seperti ustadzah, musyrifah dan lain sebagainya, maka kedekatan dengan anak asuh akan sulit dilakukan. Dikarenakan panggilan-panggilan kaku tersebut menjadi pembatas bahwa mereka sebatas guru dan murid, sedangkan yang dibutuhkan dalam hal ini adalah kedekatan layaknya orang tua pada anaknya.

Pola koordinasi wali asuh dengan pengurus BK wilayah dan BK daerah ialah dengan adanya evaluasi setiap seminggu sekali dengan BK daerah, terkait sejauh mana usaha yang dilakukan wali asuh, apa saja kendala yang dihadapi dan belum memerlukan pemecahan masalahnya. Hasil dari evaluasi daerah disampaikan pada BK wilayah oleh BK masing-masing daerah termasuk kendala yang belum terpecahkan didaerah maka akan dicari solusinya oleh BK wilayah. 
Sampai akhirnya BK wilayah melaporkan hasil evaluasi bulanan serta kendala yang dihadapi kepada jajaran pengasuh yang menangani BK khususnya kewaliasuhan. Setiap 3 bulan sekali diadakan pelatihan kewaliasuhan dengan mengundang narasumber ahli untuk menambah dan memperdalam pemahaman wali asuh terhadap praktek kewaliasuhan yang baik dan benar.

\section{E. Kesimpulan}

Dari paparan di atas, mengindikasikan bahwa wali asuh menjadi sesuatu yang sangat penting dan mendesak untuk di implementasikan dalam praksis pendidikan khususnya pada masyarakat pesantren. Karena wali asuh berperan urgen dalam optimalisasi kegiatan santri dengan membina dan mendidik santri secara personal sebagaimana orang tua kepada anaknya atau secara garis besar wali asuh adalah pengganti orang tua sementara selama berada di pesantren. Selain itu, wali asuh juga berfungsi sebagai pembina emosional santri yaitu sebagai konselor islam bagi anak asuhnya. Karena dibutuhkan kepekaan dan pemahaman yang luas untuk memahami psikologis santri. Sehingga peran wali asuh sebagai konselor Islam merupakan salah satu urgensi dalam membentuk wali asuh yang ideal di pesantren. Selain sebagai konselor Islam, wali asuh juga berperan sebagai motivator bagi anak asuhnya, melihat mayoritas santri masih tergolong labil sehingga selalu membutuhkan dorongan (motivasi) yang kuat dari orang terdekatnya.

Beberapa teori diatas menjadi penunjang urgen bagi keberhasilan wali asuh dalam proses pendekatan kepada santri. Semakin dekat, semakin pengertian dan semakin paham seorang wali asuh terhadap anak asuhnya. Maka, keberadaan wali asuh akan mudah diterima, disenangi dan lebih dipercaya oleh anak asuhnya. Dengan hal ini dapat dipastikan optimalisasi kegiatan pesantren akan meningkat.

Adanya wali asuh menjadi solusi paling efektif dalam menanggulangi berbagai problematika yang dihadapi beberapa pesantren modern dan semi modern di Indonesia. Peran wali asuh yang menjadi titik sentral dalam efektifitas kegiatan santri yang bersifat kegiatan pesantren maupun pribadi santri, maka dibutuhkan waktu yang ekstra bagi seorang wali asuh, guna menciptakan wali asuh ideal yang nantinya benar-benar bisa menjadi pengganti orang tua sementara bagi santri selama di pensatren. Maka, perlunya membedakan fungsi wali asuh dengan pengurus. Pengurus lebih difungsikan kepada optimalisasi kegiatan struktural kepesantrenan sedangkan wali asuh lebih difungsikan kepada pembinaan dan pendidikan personal santri.

\section{F. Referensi}

A.M., Sardiman. Interaksi dan Motivasi Belajar Mengajar. Jakarta: Raja Grafindo Persada, 2012. 
Alfi Najmatil Ilmy, Abd. Hamid Wahid, Chusnul Muali

Adz-Dzaky, Hamdani Bakrana. Konseling dan Psikoterapi Islam. Yogyakarta: Fajar Pustaka, 2002.

Amin, Samsul Munir. Bimbingan dan Konseling Islam. Jakarta: Amzah, 2010.

Asrori, M. Psikologi Pembelajaran. Bandung: Wacana Prima, 2007.

Awwaliyah, Hasan Baharun dan Robiatul. "Pendidikan Multikultural dalam Menanggulangi Narasi Islamisme di Indonesia." Jurnal Pendidikan Agama Islam (Journal of Islamic Education Studies), 2017: 224-243.

Aydin B., Sari Serkan V., Sahin M. "Parental Acceptance/Involvement, Self-Esteem and Academic Achievement: The Role of Hope as a Mediator." Cumhuriyet International Journal of Education-CIJE, 2014: 37-48.

Baharun, Hasan. Manajemen Strategi Peningkatan Mutu Pendidikan Pondok Pesantren (Studi Di Pondok Pesantren Nurul Jadid Paiton Probolinggo). Tesis Program Pascasarjana, Universitas Islam Negeri, 2006.

Baharun, Hasan. "Pendidikan Anak dalam Keluarga; Telaah Epistemologis." Pedagogik, 2016: 96-107.

-. Pengembangan Kurikulum: Teori Dan Praktik (Konsep, Prinsip, Model, Pendekatan Dan Langkah-Langkah Pengembangan Kurikulum PAI). Yogyakarta: Cantrik Pustaka, 2017.

Baharun, Hasan. "Total Moral Quality: A New Approach for Character Education in Pesantren." Ulumuna, 2017: 57-80.

Derald Wing Sue, Patricia Arredondo, and Roderick J. Mcdavis. "Multicultural Counseling Competencies and Standards." Journal of Counseling \& Development, 1992.

Dini, F. O., dan Indrijati, H. "Hubungan antara Kesepian dengan Perilaku Agresif pada Anak Didik di Lembaga Pemasyarakatan Anak Blitar." Jurnal Psikologi Kepribadian Dan Sosia, 2014.

Djaali. Psikologi Pendidikan. Jakarta: Bumi Aksara, 2007.

Exum, Jennifer Baggerly and Herbert A. "Counseling Children After Natural Disasters: Guidance for Family Therapists." The American Journal of Family Therapy, 2008: 79-93.

Geertz. Abangan, Santri, dan Priyayi dalam Masyarakat Jawa. Jakarta: Pustaka, 1981.

Hamalik, Oemar. Proses Belajar Mengajar. PT Bumi Aksara, 2001. 
Handayani, W. Psikologi Keluarga. Jakarta: Pustaka Utama, 2006.

Heaven, P., dan Ciarrochi, J. "Parental Style, Gender and the Development of Hope and Self-Esteem." European Journal of Personality, 2008: 22.

Irwanto, Zain. "Perilaku Agresif dan Penangananya Melalui Konseling Islami." Jurnal Psikologi Pendidikan \& Konseling, 2017.

Kushman J.W. et.al. This isn't the Place for Me: School dropout. Alexandria: American Counselling Association, 2000.

Marzuki. Prinsip Dasar Akhlak Mulia Pengantar Studi Konsep-Konsep Dasar Etika dalam Islam. Yogyakarta: Debut Wahana Press, 2009.

Mu'niah. Materi Pendidikan Agama Islam untuk Perguruan Tinggi. Yogyakarta: Ar-Ruzz Media, 2011.

Muali, Chusnul. "Rasionalitas Konsepsi Budaya Nusantara dalam Menggagas Pendidikan Karakter Bangsa Multikultural." Jurnal Islam Nusantara, 2017: 105117.

Mudjiono, Dimyati dan. Belajar dan Pembelajaran. Jakarta: Rineka Cipta, 2009.

Muhakamurrohman, Ahmad. "Pesantren: Santri, Kiai, dan Tradisi." Jurnal Kebudayaan Islam, 2014.

Muhibbin, S. Psikologi Pendidikan dengan Pendekatan Baru. Bandung: PT. Remaja Rosdakarya, 2002.

Mulyasa. Standar Kompetensi dan Sertifikasi Guru. Bandung: PT. Remaja Rosdakarya, 2008.

Ngalim, P. Psikologi Pendidikan. Bandung: Sinar Baru Algesindo, 2007.

Notosoedirdjo, M. dan Latipun. Kesehatan Mental. Malang: UPT Universitas Muhammadiyah, Malang Press, 2011.

Papalia, D. E., Wendkos, S., dan Feldman, R.D. Human Development. Jakarta: Kencana, 2008.

Peters, R. S. The Concept of Motivation. London: Routledge, 1958.

Pranowo, M. Bambang. Islam Faktual, Antara Tradisi dan Relasi Kuasa. Jakarta: Adicita Karya Nusa, 1998.

Putri Risthantri, Ajat Sudrajat. "Hubungan Antara Pola Asuh Orang Tua Dan Ketaatan Beribadah Dengan Perilaku Sopan Santun Peserta Didik." Jurnal Pendidikan IPS, 2015. 
Restu, Y. dan Yusri. "Studi tentang Perilaku Agresif Siswa di Sekolah." Jurnal Ilmiah Konseling, 2013: 243-249.

RI, Departemen Agama. Cordova Al-Qur'an dan Terjemah. Bandung: PT. Sygma Examedia Arkan leema, 2009.

Shaffer, DR \& Kipp K. Developmental Psychology: Childhood and Adolescence, 9th Edition. Canada: Wadswort Cengage Learning, 2014.

Shorey, H.S., Snyder, C. R., Yang, X. \& Lewin, M.R. "The Role of Hope as a Mediator in Recollected Parenting, Adult Attachment and Mental Health." Journal of Social and Clinical Psychology, 2003: 685-715.

Subhan, Arief. Lembaga Pendidikan Islam Indonesia Abad ke-20 Pergumulan Antara Modernisasi dan Identitas. Jakarta: Kencana, 2012.

Ujiningsih dan Antoro, S.D. "Pembudayaan sikap sopan santun di rumah dan di sekolah sebagai upaya untuk meningkatkan karakter siswa." Temu Ilmiah Nasional Guru II 2010 Universitas Terbuka. 2010. 2.

Waluya, O. D., dan Rakhmadianti, A. K. "Perilaku Agresif ditinjau dari Jenis Tontonan Film pada Siswa SMAN 70 Jakarta Selatan." Jurnal Psikologi, 2008.

Yusuf, S. Psikologi Perkembangan Anak \& Remaja. Bandung: PT. Remaja Rosdakarya, 2008.

Zahra, Akmal Mundiri dan Irma. "Implementasi Metode STIFIn Dalam Meningkatkan Kemampuan Menghafal Al-Qur'an Di Rumah Qur'an STIFIn Paiton Probolinggo." Jurnal Pendidikan Agama Islam (Journal of Islamic Education Studies), 2017: 201. 